\title{
Campylobacter insulaenigrae bacteremia with meningitis: a case report
}

\author{
Moe Kyotani ${ }^{1}$, Tsuneaki Kenzaka ${ }^{1,2^{*}}$ (D), Hozuka Akita ${ }^{1}$ and Soichi Arakawa ${ }^{3}$
}

\begin{abstract}
Background: The bacterium Campylobacter insulaenigrae was first isolated from marine mammals of Scotland in 2004. Only one case of $C$. insulaenigrae infection in humans has been previously reported.

Case presentation: An 89-year-old Japanese man without dementia was admitted to our hospital, because he presented with a fever of $38^{\circ} \mathrm{C}$ and weakness in right leg since 5 days. He had organized chronic subdural hematoma (CSH), and no history of pre-infection. At the time of admission, he had paralysis of the extraocular muscle, ataxia, and low manual muscle test score of the right side. He was suspected to have Miller Fisher syndrome; however, these symptoms improved without any treatment. On day 22 in the hospital, the patient presented a fever of $38.8^{\circ} \mathrm{C}$, left cranial nerve disorder, and hemiplegia. On day 25 , the patient presented with signs of meningeal irritation; cerebrospinal fluid examination indicated an increase in the number of apocytes and a low glucose level. A contrast magnetic resonance imaging (MRI) scan of the patient's head indicated a contrast enhancement effect in his right meninges. The blood culture showed presence of spirillums; 165 rRNA gene sequencing confirmed that the spirillums in the blood culture were Campylobacter insulaenigrae (C. insulaenigrae). We started treatment with meropenem for bacteremia and meningitis. When the symptoms improved, meropenem was replaced with ampicillin, based on the result of the drug sensitivity test. The treatment continued for 4 weeks.

Conclusions: We report the first case of meningitis caused by $C$. insulaenigrae bacteremia in humans, and the second clinical report of $C$. insulaenigrae infection in humans. The bacterial strains isolated from humans and marine mammals had different genotypes. This suggests that different genotypes could be responsible for differences in the hosts. Further case studies are needed to establish the reasons behind the difference in the manifestations of $C$. insulaenigrae infections reported so far.
\end{abstract}

Keywords: Campylobacter insulaenigrae, Meningitis, Bacteremia, Marine mammals, Meningeal irritation

\section{Background}

Campylobacter insulaenigrae was first isolated from the rectal swab of marine mammals (seals and a porpoise) of Scotland by Foster et al. in 2004 [1]. Later on, the bacterium was isolated from northern elephant seals in California [2] and the south American sea lion in Chile [3].

\footnotetext{
* Correspondence: smile.kenzaka@jichi.ac.jp

'Department of Internal Medicine, Hyogo Prefectural Tamba Medical Center, 2002-7 Iso, Hikami-cho, Tamba, Hyogo 669-3495, Japan

${ }^{2}$ Division of Community Medicine and Career Development, Kobe University Graduate School of Medicine, 2-1-5, Arata-cho, Hyogo-ku, Kobe, Hyogo 652-0032, Japan

Full list of author information is available at the end of the article
}

C. insulaenigrae is phylogenetically related to C. jejuni, C. coli, and C. lari [1]. The first case of infection caused by $C$. insulaenigrae in humans was reported by Chua $\mathrm{K}$ et al. in 2007 [4]. We report a case of C. insulaenigrae bacteremia with meningitis, as the second clinical case of C. insulaenigrae infection in humans.

\section{Case presentation}

An 89-year-old Japanese man without dementia presented with a fever of $38^{\circ} \mathrm{C}$ and weakness in right leg since 5 days. His symptoms showed no improvement; and therefore, he was admitted to our hospital. The

(c) The Author(s). 2021 Open Access This article is licensed under a Creative Commons Attribution 4.0 International License, which permits use, sharing, adaptation, distribution and reproduction in any medium or format, as long as you give appropriate credit to the original author(s) and the source, provide a link to the Creative Commons licence, and indicate if changes were made. The images or other third party material in this article are included in the article's Creative Commons licence, unless indicated otherwise in a credit line to the material. If material is not included in the article's Creative Commons licence and your intended use is not permitted by statutory regulation or exceeds the permitted use, you will need to obtain permission directly from the copyright holder. To view a copy of this licence, visit http://creativecommons.org/licenses/by/4.0/. The Creative Commons Public Domain Dedication waiver (http://creativecommons.org/publicdomain/zero/1.0/) applies to the data made available in this article, unless otherwise stated in a credit line to the data. 
patient reported no interaction with marine mammals (e.g. going to the aquarium, a household pet), no history of previous infection caused by them, and no event of eating raw fish.

The patient had a medical history of hypertension, glaucoma, and organized chronic subdural hematoma $(\mathrm{CSH})$, which was treated with craterization at the age of 80 -years. He had been prescribed the following medication: valsartan, $80 \mathrm{mg} /$ day; valproic acid, $800 \mathrm{mg} /$ day; magnesium oxide, $750 \mathrm{mg} /$ day; pantosin, $3.0 \mathrm{~g} /$ day; and triazolam, $0.25 \mathrm{mg} /$ day.

At the time of admission, the patient was conscious and lucid, and his vital signs were as follows: heart rate, 79 beats/min and regular; body temperature, $38.0^{\circ} \mathrm{C}$ blood pressure, $157 / 86 \mathrm{mmHg}$; respiratory rate, 16 breaths/min; peripheral oxygen saturation, $95 \%$ in room air. Physical test results showed paralysis of extraocular muscle at downward and left gaze, ataxia, and low manual muscle test (MMT) score of the right side. No meningeal irritation signs (jolt accentuation, neck stiffness, Kernig's sign, and Brudzinski's sign) were observed at the time of admission. Two sets of blood culture on day 2 were sterile, and cerebrospinal fluid (CSF) could not be obtained during admission despite all efforts. Head computed tomography (CT) scans and magnetic resonance imaging (MRI) scans were unremarkable, except for the presence of organized CSH. Based on these findings and consultation with the neurologist, we suspected that the patient had Miller Fisher syndrome. However, the anti-ganglioside antibody test result was negative.

After admission, the fever and neurological symptoms of the patient improved without treatment. He was discharged from the hospital and he stayed overnight at his home from day 21 to 22; he did not come into contact with saltwater or marine mammals and did not eat raw fish during his stay at home. $\mathrm{He}$ returned to the hospital on day 22 and presented with a fever of $38.8^{\circ} \mathrm{C}$ and left hemiplegia with unconsciousness. Laboratory investigation results on day 24 were as follows (Table 1): white blood cell (WBC) count, $8610 / \mu \mathrm{L}$ (neutrophils, 84.8\%; lymphocytes, 9.3\%; and monocytes, $5.8 \%$ ); and C-reactive protein (CRP), $19.42 \mathrm{mg} / \mathrm{dL}$. Neurological findings on day 25 included positive meningeal irritation signs (Jolt accentuation and neck stiffness), ocular motility disorder in all directions, left cranial nerve disorder, low MMT score of left upper and lower limb, and extrapyramidal disorder. CSF examination results on the same day were as follows: initial pressure, $27 \mathrm{cmH}_{2} \mathrm{O}$; number of cells, $69 / \mu \mathrm{L}$ (number of monocytes, $13 / \mu \mathrm{L}$; and number of apocytes $56 / \mu \mathrm{L})$; protein, $168 \mathrm{mg} / \mathrm{dL}$; and glucose level, $39 \mathrm{mg} / \mathrm{dL}$ (blood glucose level, $122 \mathrm{mg} /$ $\mathrm{dL}$ ). A phase-contrast MRI of the patient's head indicated a contrast enhancement effect in his right
Table 1 Laboratory investigation results of the patient on day 24

\begin{tabular}{|c|c|c|}
\hline Parameter & Recorded value & Standard value \\
\hline White blood cell count & $8610 / \mu \mathrm{L}$ & $4700-8700 / \mu \mathrm{L}$ \\
\hline Neutrophils & $84.8 \%$ & $42-72 \%$ \\
\hline Lymphocyte & $9.3 \%$ & $18-50 \%$ \\
\hline Monocyte & $5.8 \%$ & $1-8 \%$ \\
\hline Hemoglobin & $12.5 \mathrm{~g} / \mathrm{dL}$ & $13-17 \mathrm{~g} / \mathrm{dL}$ \\
\hline Hematocrit & $36.3 \%$ & $40-50 \%$ \\
\hline Platelet count & $11.3 \times 10^{4} / \mu \mathrm{L}$ & $15-35 \times 10^{4} / \mu \mathrm{L}$ \\
\hline C-reactive protein & $19.42 \mathrm{mg} / \mathrm{dL}$ & $\leq 0.3 \mathrm{mg} / \mathrm{dL}$ \\
\hline Total protein & $6.3 \mathrm{~g} / \mathrm{dL}$ & $6.7-8.3 \mathrm{~g} / \mathrm{dL}$ \\
\hline Albumin & $2.6 \mathrm{~g} / \mathrm{dL}$ & $3.9-4.9 \mathrm{~g} / \mathrm{dL}$ \\
\hline Total bilirubin & $1.4 \mathrm{mg} / \mathrm{dL}$ & $0.2-1.2 \mathrm{mg} / \mathrm{dL}$ \\
\hline Aspartate aminotransferase & $21 \mathrm{U} / \mathrm{L}$ & 8-38 U/L \\
\hline Alanine aminotransferase & $15 \mathrm{U} / \mathrm{L}$ & 4-44 U/L \\
\hline Lactate dehydrogenase & $158 \mathrm{U} / \mathrm{L}$ & $120-230 \mathrm{U} / \mathrm{L}$ \\
\hline Creatine phosphokinase & $244 \mathrm{U} / \mathrm{L}$ & $62-287 \mathrm{U} / \mathrm{L}$ \\
\hline Blood urea nitrogen & $27.0 \mathrm{mg} / \mathrm{dL}$ & $8.5-20 \mathrm{mg} / \mathrm{dL}$ \\
\hline Creatinine & $0.76 \mathrm{mg} / \mathrm{dL}$ & $0.53-1.02 \mathrm{mg} / \mathrm{dL}$ \\
\hline Sodium & $131 \mathrm{mEq} / \mathrm{L}$ & $134-147$ mEq/L \\
\hline Potassium & $3.9 \mathrm{mEq} / \mathrm{L}$ & $3.5-5.0 \mathrm{mEq} / \mathrm{L}$ \\
\hline Chloride & $98 \mathrm{mEq} / \mathrm{L}$ & 98-108 mEq/L \\
\hline Glucose & $187 \mathrm{mg} / \mathrm{dL}$ & $70-109 \mathrm{mg} / \mathrm{dL}$ \\
\hline
\end{tabular}

The patient presented with fever and he was re-hospitalized on day 24. These are the laboratory investigation results during the re-admission

meninges and cerebral edema in the frontal and parietal lobes, and blood culture reports showed the presence of spirillums. These results suggested bacteremia and meningitis. Taking into consideration the pharmacodynamics of antibiotics in CSF, we prescribed the patient with meropenem $(2 \mathrm{~g}$ every $8 \mathrm{~h})$ from day 24. The symptoms and laboratory findings improved after starting the treatment (Fig. 1).

Blood culture results on day 22 showed the presence of gram-negative spirillums belonging to the genus Campylobacter; however, the species of the bacteria was not confirmed. 16S rRNA gene sequencing of the bacteria obtained from the blood culture identified the bacterial strain as Campylobacter insulaenigrae. The number of cells (monocytes and apocytes) and glucose levels in CSF samples were a clear indicator of bacterial meningitis; however, the culture and genetic analyses showed that the CSF samples were sterile. We changed the treatment from meropenem to ampicillin ( $2 \mathrm{~g}$ every $4 \mathrm{~h}$ ) from day 32 , based on the result of the drug sensitivity test using the disk method (Table 2) and discontinued the treatment on day 53 (total duration 29 days); we observed that the dayto-day activity level of the patient reached levels similar to that before contracting bacteremia. 


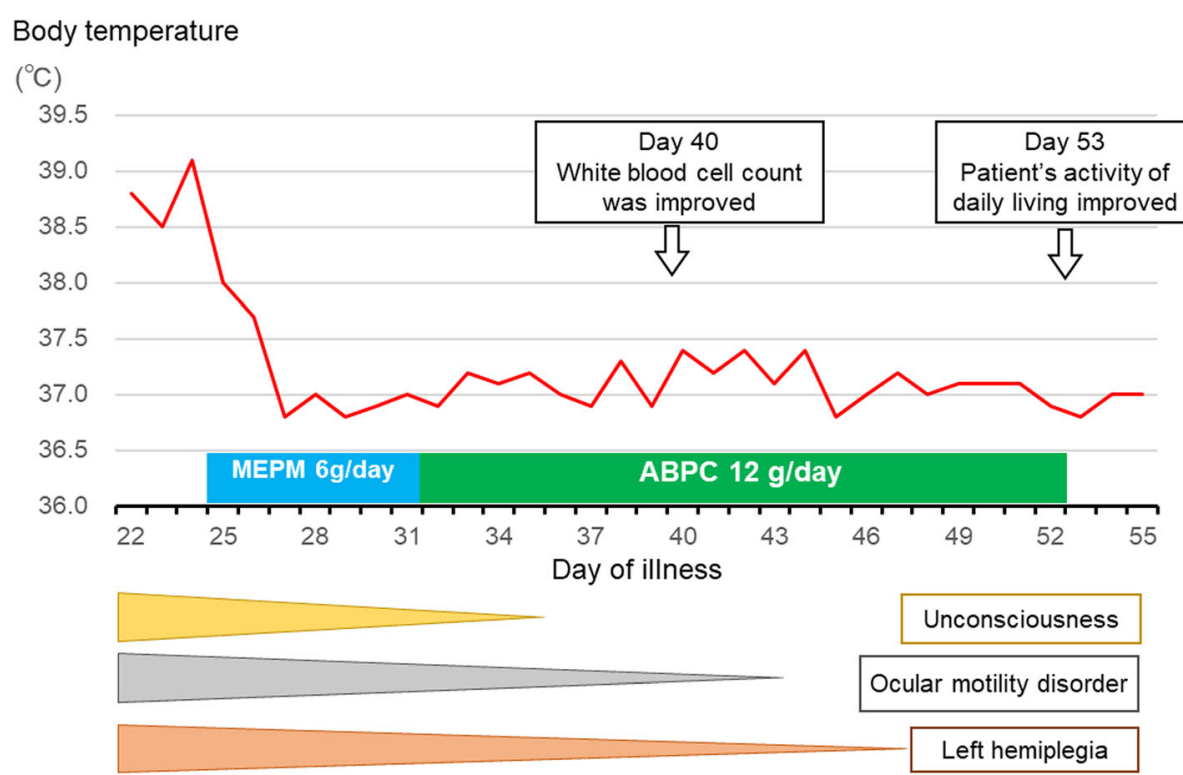

Fig. 1 Clinical course after starting treatment. MEPM, meropenem; ABPC, ampicillin

\section{Discussion and conclusion}

This case report presents a case of $C$. insulaenigrae bacteremia with meningitis. To the best of our knowledge, this is the first report of meningitis caused by $C$. insulaenigrae in humans, and the second report of infection by $C$. insulaenigrae in humans.

C. insulaenigrae was first isolated from marine mammals [1]; however, the patient in this study reported no contact with any marine mammals. We enquired about

Table 2 Results of drug sensitivity test for Campylobacter insulaenigrae cultured on day 22

\begin{tabular}{|c|c|c|c|c|}
\hline \multicolumn{3}{|l|}{ Disk method } & \multicolumn{2}{|l|}{ Etest } \\
\hline Antibiotic & $\begin{array}{l}\text { Zone } \\
(\mathrm{mm})\end{array}$ & & Antibiotic & $\begin{array}{l}\text { MIC } \\
(\mu \mathrm{g} / \mathrm{ml}))\end{array}$ \\
\hline Ampicillin & 33 & $\mathrm{~S}$ & Ampicillin & 8 \\
\hline Cefotaxime & $>30$ & $S$ & Ceftriaxone & 0.25 \\
\hline Ceftriaxone & 8 & $\mathrm{R}$ & Imipenem & 0.125 \\
\hline Cefaclor & 24 & $S$ & Meropenem & 0.003 \\
\hline Meropenem & $>30$ & $\mathrm{~S}$ & Minocycline & $<0.016$ \\
\hline Erythromycin & $>30$ & $\mathrm{~S}$ & Sulfamethoxazole-Trimethoprim & $>32$ \\
\hline Fosfomycin & 0 & $\mathrm{R}$ & Cefepime & 1.0 \\
\hline \multirow[t]{4}{*}{ Levofloxacin } & 10 & $\mathrm{R}$ & Clindamycin & 0.064 \\
\hline & & & Ciprofloxacin & 2 \\
\hline & & & Levofloxacin & 2 \\
\hline & & & Tazobactam/Piperacillin & $<0.016$ \\
\hline
\end{tabular}

The "S" and " $\mathrm{R}$ " represent "susceptible" and "resistant", respectively. The result of the Etest was obtained after the treatment. The assignment of $S$ or $R$ was according to the standard values for Campylobacter, according to the Clinical and Laboratory Standard Institute (CLSI). The assessment of the Etest was difficult, as a standard was not specified by the CLSI eating raw fish; however, we could not verify the history of contact with marine mammals. Therefore, the portal of entry was uncertain in this case, similar to the report by Chua $\mathrm{K}$ et al. [4] (Table 3 ).

The first case of infection due to C. insulaenigrae was reported by Chua $\mathrm{K}$ et al. in 2007 [4]; the patient, a 60year-old woman under hemodialysis, for treating autosomal dominant adult polycystic kidney, presented with gastroenteritis diagnosed by fever, diarrhea, and stomachache.

In this study, the CSF culture did not show the presence of $C$. insulaenigrae; however, the low glucose levels in the CSF suggested bacterial meningitis. In addition, we could not identify any other sites in the patient that were affected by bacteremia. Therefore, we clinically diagnosed the patient with meningitis caused by $C$. insulaenigrae. The organized $\mathrm{CSH}$ had not changed after craterization (done 9 years ago); and therefore, the patient's neurological findings could have been induced by transient cerebral edema and meningitis associated with organized CSH. The symptoms and findings at the time of admission improved without any treatment, blood culture results on day 2 were sterile, and CSF could not be obtained; therefore, the symptoms were suspected to have occurred because of chronic meningitis.

There are two possible routes of entry: 1) the patient had contracted the $C$. insulaenigrae infection before admission, which was not identified by the microbiological results at the time of admission. 2) He contracted the infection during his stay at home (day 21 to 22); he was readmitted to the hospital on day 22 when he presented with a fever and neurological symptoms. However, he 
Table 3 Cases of Campylobacter insulaenigrae infection in humans

\begin{tabular}{lll}
\hline & Chua K et al. (2007) [4] & Current Study (2015) \\
\hline Country & Australia & Japan \\
Age, Sex & 60-year-old woman & 89-year-old man \\
Symptoms & Fever, abdominal pain, and diarrhea & Fever and weakness in legs \\
Infection site & Intestinal canal, blood & meninges, blood \\
Medical history & Hemodialysis for autosomal dominant adult polycystic kidney and & Organized chronic subdural hematoma and \\
& liver disease & hypertension \\
Interaction with marine & None & None \\
mammals & & \\
Antibiotics for treatment & Ciprofloxacin, Azithromycin, and Meropenem & Meropenem and Ampicillin \\
Duration of therapy & 24 weeks & 4 weeks \\
GenBank & EF433401 & DQ174183
\end{tabular}

The table compares the characteristics in the current study and the previous study reported in 2007 [4]. In both cases, there is no interaction with marine mammals and the portal of entry was uncertain in both of them

confirmed that he was not in contact with salt water or marine mammals during that time.

We compared the characteristics of all the C. insulaenigrae strains reported until date (Table 4). The strains isolated from humans were able to grow at $42{ }^{\circ} \mathrm{C}$, while the strains isolated from marine mammals were unable to grow at this temperature. In addition, the gene sequences for the $16 \mathrm{~S}$ rRNA, obtained from GenBank were different between the strains isolated from humans and the strains isolated from marine mammals. This suggested that there are multiple genotypes of the bacterial

Table 4 Characteristics of Campylobacter insulaenigrae isolated from marine mammals and humans

\begin{tabular}{|c|c|c|c|}
\hline Characteristics & $\begin{array}{l}\text { Foster G et al. } \\
(2004)[1]\end{array}$ & $\begin{array}{l}\text { Chua K et al. } \\
\text { (2007) [4] }\end{array}$ & $\begin{array}{l}\text { Patient in this } \\
\text { study(2015) }\end{array}$ \\
\hline Host & $\begin{array}{l}\text { Marine } \\
\text { mammal }\end{array}$ & human & human \\
\hline \multicolumn{4}{|l|}{ Growth at/in: } \\
\hline $25^{\circ} \mathrm{C}$ & - & - & \\
\hline $42^{\circ} \mathrm{C}$ & - & + & + \\
\hline $1 \%$ glycine & + & - & \\
\hline $2 \% \mathrm{NaCl}$ & - & - & + \\
\hline Oxidase & + & + & + \\
\hline $\begin{array}{l}\text { Hippurate } \\
\text { hydrolysis }\end{array}$ & - & - & - \\
\hline Cephalothin & - & - & - \\
\hline Nalidixic acid & - & - & - \\
\hline $\begin{array}{l}\text { Microaerophilic } \\
\text { growth }\end{array}$ & + & + & + \\
\hline $\begin{array}{l}\text { Anaerobic } \\
\text { growth }\end{array}$ & - & - & - \\
\hline GenBank & AJ620504 & EF433401 & DQ174183 \\
\hline
\end{tabular}

The growth characteristics of the $C$. insulaenigrae strains reported till date. The strains isolated from humans and marine mammals have differences in growing temperature and genotypes. These factors might relate to the pathogenicity or infection sites strain, which could correspond to the different hosts or infection sites. Considering that the isolate from the current study caused infection in an immunocompetent patient, the difference in genotypes could be related to the differences in the pathogenicity of the bacterial strain.

TOnly two cases of $C$. insulaenigrae infection in humans have been reported so far, to the best of our knowledge; however, there is a possibility that $C$. insulaenigrae infection was reported as $C$. jejuni infection, because of the absence of sodium hippurate hydrolysis in both the strains. Whole genome sequencing of the two $C$. insulaenigrae strains might help uncover the reasons behind the differences in the infection sites and infection manifestation between these two strains. Further cases are needed to identify the differences in the characteristics of the bacterial strains arising from the different genotypes.

\section{Abbreviations \\ CSF: Cerebrospinal fluid; CSH: Chronic subdural hematoma; MRI: Magnetic resonance imaging; MMT: Manual muscle test; CT: Computed tomography; WBC: White blood cell; CRP: C-reactive protein

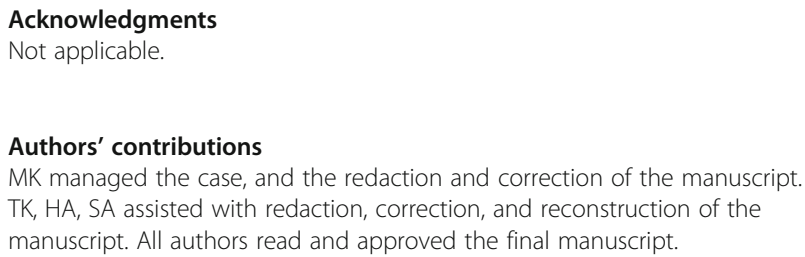

Availability of data and materials

All data generated or analyzed during this study are included in this published article. 


\section{Declarations}

\section{Ethics approval and consent to participate}

Ethics approval was not required, because this is a case report. Therefore, the need for ethics approval was waived by the ethics committee of Hyogo

Prefectural Tamba Medical Center.

\section{Consent for publication}

Written informed consent was obtained from the patient for publication of this case report and the accompanying images. A copy of the written consent is available for review by the Editor of this journal.

\section{Competing interests}

The authors declare that they have no competing interests.

\section{Author details}

'Department of Internal Medicine, Hyogo Prefectural Tamba Medical Center, 2002-7 Iso, Hikami-cho, Tamba, Hyogo 669-3495, Japan. ${ }^{2}$ Division of Community Medicine and Career Development, Kobe University Graduate School of Medicine, 2-1-5, Arata-cho, Hyogo-ku, Kobe, Hyogo 652-0032,

Japan. ${ }^{3}$ Sanda City Hospital, 3-1-1, Keyaki-dai, Sanda, Hyogo 669-1326, Japan.

Received: 25 September 2019 Accepted: 24 June 2021

Published online: 01 July 2021

\section{References}

1. Foster G, Holmes B, Steigerwalt AG, Lawson PA, Thorne P, Byrer DE, et al. Campylobacter insulaenigrae sp. nov., isolated from marine mammals. Int J Syst Evol Micr. 2004;54(6):2369-73. https://doi.org/10.1099/ijs.0.63147-0.

2. Stoddard RA, Miller WG, Foley JE, Lawrence J, Gulland FMD, Conrad PA, et al. Campylobacter insulaenigrae isolates from northern elephant seals (Mirounga angustirostris) in California. Appl Environ Microbiol. 2007;73(6): 1729-35. https://doi.org/10.1128/AEM.01816-06.

3. González M, Villanueva MP, Debruyne L, Vandamme P, Fernández $H$. Campylobacter insulaenigrae: first isolation report from south American sea lion (Otaria Flavescens, (Shaw, 1800)). Braz J Microbiol. 2011;42(1):261-5. https://doi.org/10.1590/S1517-83822011000100033.

4. Chua K, Gürtler V, Montgomery J, Fraenkel M, Mayall BC, Grayson ML. Campylobacter insulaenigrae causing septicaemia and enteritis. J Med Microbiol. 2007;56(11):1565-7. https://doi.org/10.1099/jmm.0.47366-0.

\section{Publisher's Note}

Springer Nature remains neutral with regard to jurisdictional claims in published maps and institutional affiliations. 